\title{
West German government reeling from export disclosures
}

Munich

THE mushrooming story of West German participation in the alleged chemical weapons factory at Rabta in Libya and in biological and atomic weapons programmes in Iraq and India has plunged Christian Democrat Helmut Kohl into the gravest crisis of his six-year chancellorship.

On 30 January, the news magazine Spiegel revealed that the West German subsidiary of the US-based Sigma chemical company had delivered $100 \mathrm{mg}$ of the deadly mycotoxins HT-2 and T-2 to Iraq in 1987 for DM 60,000. Government spokesman Friedhelm Ost defended the decision not to require an export licence, saying that the amount was so small that the toxins could only have been used for scientific purposes. A toxicologist at the WalterStraub-Institute in Munich said that 100 mg was indeed too little toxin to use for biological weapons, but added that research on antidotes to the toxins or on other defensive measures would have been possible.

On the same day, Spiegel revealed that Degussa AG of Frankfurt had exported 95 $\mathrm{kg}$ of beryllium to India in 1984. Beryllium can enhance the power of atomic bombs, although it also has non-military uses. Much of the beryllium sent to India had been imported from the United States, and US officials said that West Germany should have applied for a licence to reexport it. The government says it approved of the export because it had assurances that the beryllium would be used for non-nuclear purposes. The beryllium was reportedly delivered to the Bhabha Atomic Research Center in Trombay.

Potentially even more damaging to the government was the disclosure that stateowned Salzgitter Industriebau AG had apparently known since 1985 that
Imhausen's "pharmaceuticals factory", for which it was creating blueprints, was destined for Libya and not for Hong Kong. This emerged from documents discovered by Salzgitter officials and turned over to prosecutors on 29 January.

The revelation was the first potential "evidence that would stand up in court" linking privately owned ImhausenChemie $\mathrm{GmbH}$ with the Libyan plant. On 10 January, Chancellor Kohl had vigorously denied that such evidence existed. Officials at Salzgitter say that they were "fooled" by Imhausen and that they did not know the real destination of the "pharmaceuticals factory".

The government has intensified the search for evidence in the Rabta case and proposed harsher sanctions for West German citizens abroad who are found to be involved in the construction of biological or chemical weapons factories

There has yet to be any serious discussion about changing the West German export laws. The current system allows all exports except those specifically restricted; the US system forbids all exports except those specifically allowed.

But even if new laws are enacted quickly, the government's credibility may have sustained irrevocable damage. The durable coalition between Christian Democrats (CDU) and Free Democrats is now fragile. Other developments, especially a devastating defeat for the CDU in the West Berlin state elections on 29 January, have contributed to the malaise.

Kohl dispatched two top envoys to Washington last week to mend fences and curry favour with the Bush administration. He must now prepare answers to 49 questions asked by the opposition regarding government behaviour in the Libya affair.

\section{Cover story hits the wrong target}

\section{Washington}

THE cover of a scientific products catalogue from PGC Scientifics Corporation of Gaithersburg, Maryland, has elicited howls of protest from researchers, particularly at NIH who are appalled by its inappropriateness. The cover depicts a man and a woman dressed in white laboratory coats - but made up to look like film versions of "mad scientists" — attempting to force a blue liquid down a white rat's throat.

Robert Whitney, head of the NIH division of research services, says his office has received at least a dozen calls from NIH researchers complaining about the cover. He says the cover conveys "absolutely the wrong message" about researchers and how they work, especially with regard to animals. "Whoever came up with the advertisement must have been living in Siberia for the last $\mathbf{1 0}$ years. It's absolutely inexcusable", says Whitney.

NIH is planning to write a letter of protest to the company, but is not contemplating any boycott or sanctions.

Gary Bechanan, the marketing manager of the company, says the cover was intended as a humorous portrayal of the common stereotype of scientists, and that it was "not our intent to imply animal abuse". $\mathrm{He}$ and the president of the company are responding personally to all complaints about the cover, and an apology letter will be printed in the new edition of the catalogue, to be released in August. In the meantime, the current catalogue is being reprinted with an old cover which depicts a cityscape made from labware.

Joseph Palca \& Carol Ezzell

The cover you won't see.

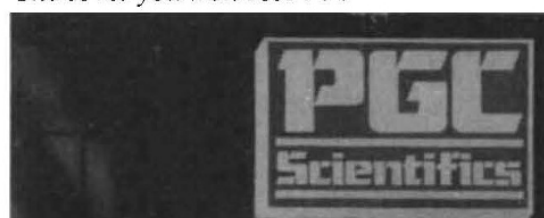

\section{US science literacy could be better}

\section{Boston}

STUDENTs from the United States and French-speaking Ontario in Canada have been ranked last in a survey of mathematics and science performance of 13year-olds from six industrialized nations, according to a report released last week by the Educational Testing Service, based in Princeton, New Jersey. The report's findings, called a "national tragedy" by the new US Secretary of Education, Lauro Cavazos, will further fuel growing concern about mathematics and science literacy in the United States.

The survey tested 24,000 students from Britain, Ireland, Spain and South Korea, as well as the United States and four Can- adian provinces. South Korean students scored highest in both mathematics and science, followed closely by students from British Columbia, Canada. According to the Educational Testing Service, the survey is the first large-scale international comparison of students in this age group.

Interestingly, the findings tend to refute previous studies suggesting that there is a gender gap between boys and girls in mathematics performance. Only in Korea and Spain did boys significantly outperform girls in this test. In the science portion of the test, however, boys did better than girls everywhere except in the United States and the United Kingdom.

Seth Shulman 